\title{
Development of a novel simian adenovirus 24 based vaccine vector
}

\author{
P Abbink", RR Bradley, F Ball, D Ng'ang'a, E Borducchi, DH Barouch \\ From AIDS Vaccine 2012 \\ Boston, MA, USA. 9-12 September 2012
}

\section{Background}

Human adenovirus serotype 5 is a potent vaccine vector, but its use has been hampered by high seroprevalence amongst people in sub-Sahara Africa. Novel adenoviral vaccine vectors from strains with lower seroprevalence worldwide are being developed that can evade pre-existing immunity. Here we describe the development of a simian Ad24 (sAd24)-based vaccine vector.

\section{Methods}

Neutralizing antibodies against sAd24 were determined using a panel of 106 rhesus macaque sera and 128 human sera from Rwanda and South Africa using a luciferasebased adenovirus neutralization assay.

The immunogenicity of a single dose of 10E7, 10E 8 or $10 \mathrm{E} 9$ virus particles of sAd24-SIV Gag based vector was determined in C57BL/6 mice. SIV-Gag-specific immune responses were assessed by Db/AL11 tetramer binding assays, IFN- $\gamma$ ELISPOT assays and ICS assays.

\section{Results}

Neutralizing antibodies were found in 7\% of monkeys, all with titers $<200$. In humans from sub-Saharan Africa, $45 \%$ was positive for sAd24 neutralizing antibodies, but titers remained low and $90 \%$ had titers $<200$. In comparison, seroprevalence of Ad5 in sub-Saharan Africa is $86.4-89.5 \%$ with $61.1-78.7 \%$ of this population showing titers $>200$ and $25.1-46.8 \%$ showing titers $>1000$. Gag specific cellular immune responses elicited by sAd24-SIV Gag in mice are comparable to those seen with the human Ad26 and Ad28 vectors currently in development.

\section{Conclusion}

These data suggest that sAd24 is promising for further studies as a candidate vaccine vector.

Published: 13 September 2012

doi:10.1186/1742-4690-9-S2-P309

Cite this article as: Abbink et al.: Development of a novel simian adenovirus 24 based vaccine vector. Retrovirology 2012 9(Suppl 2):P309.

Beth Israel Deaconess Medical Center, Boston, MA, USA

Submit your next manuscript to BioMed Central and take full advantage of:

- Convenient online submission

- Thorough peer review

- No space constraints or color figure charges

- Immediate publication on acceptance

- Inclusion in PubMed, CAS, Scopus and Google Scholar

- Research which is freely available for redistribution
(C) 2012 Abbink et al; licensee BioMed Central Ltd. This is an Open Access article distributed under the terms of the Creative Commons Attribution License (http://creativecommons.org/licenses/by/2.0), which permits unrestricted use, distribution, and reproduction in any medium, provided the original work is properly cited. 